\title{
Transport relations among settlement centres in the eastern part of the Czech Republic as a potential for polycentricity
}

\author{
DANIEL SEIDENGLANZ
}

Masaryk University, Faculty of Science, Department of Geography

\begin{abstract}
Transport is one of the important factors influencing the arrangement of spatial relations and creating of spatial interactions in society. This proposition can also be applied to the forming of links within an urban system. In connection with this it is possible to point out that, to a large extent, the arrangement of transport relations also predetermines monocentric or polycentric organization of urban systems. The paper deals with an analysis of these connections, both in theory and in practice. The example of the eastern part of the Czech Republic, based on public transport supply, serves to identify transport interactions between 51 centres that make daily interactions between them possible. Apart from the typology of spatial pattern of the found transport interactions the paper also quantifies the benefits for the population of the centres, brought about by potential polycentricity (e.g. a greater plurality of choices regarding the place of daily activities). The benefits are analyzed by means of the calculation of the daily economic potential expressed as the total number of accessible jobs.
\end{abstract}

Key words: transport, urban system, polycentricity, daily economic potential, eastern part of the Czech Republic

\section{Transport relations, accessibility and polycentricity}

Transport is a phenomenon which, according to Rodrigue et al. (2006), makes it possible to overcome friction of space and thus create functional links between places of various qualities on the surface of the Earth. According to a number of authors (e.g. McBride 1996) transport interaction between various places of geographical space leads to creating complementarity which can be understood as a phenomenon within which different regions compensate their surplus and shortages, namely by exchanging people, goods and services. It is the transport that provides for the exchange of surplus and shortage goods (Seidenglanz 2008). At the same time, transport efficiency fundamentally influences transferability which manifests itself for transport users above all by time and cost of movement (Wheeler, Muller 1981).

A rapid drop in unit transport costs (Pedersen 2001) has occurred in recent decades, which is reflected in the growth of individual mobility (Kellerman 2006). A higher level of mobility allows easier accessibility of a higher number of centres, both close and more remote - as a result of which polycentricity can develop. The link between 
a high level of mobility / transport intensity and polycentricity can be analysed on two hierarchical levels:

- transport and polycentricity in the city,

- transport and polycentricity of an urban system.

\subsection{Transport and polycentricity in the city}

The high level of individual mobility in cities contributes to their gradual decentralization and spatial expansion. The changes in the distribution of population and socio-economic functions in cities and their hinterlands are usually conceptualized as residential and commercial suburbanization (Sýkora 2002), which, as a result, can even lead to the creation of secondary nodes with a higher concentration of, among others, service functions. As a consequence, a polycentric form of the city may arise.

Analyses of links between transport and the polycentric patterns of cities and urban regions are a relatively frequent topic of research in transport geography. An interesting example is the article by Gutiérrez, García-Palomares (2007) which deals with changes in transport flows in Madrid metropolitan area. The authors analyze mobility surveys conducted in 1988 and 1996 and come to the conclusion that in Madrid, a transition from the system of starfish-shaped structure of trips to the system of spider's web form of trips, characterized by a bigger spatial diversity, is currently taking place. The proportion of trips realized in central city and centripetal trips is decreasing and the proportion of centrifugal trips is slightly rising, whereas the representation of lateral suburb to suburb trips is significantly increasing. These changes can be interpreted as the very consequence of polycentricity in a metropolitan area.

The influence of urban structure on the choice of the mode of transport and the distance of travel for various purposes was studied on the example of Dutch monocentric and polycentric urban structures by Schwanen et al. (2001). The authors came to the conclusion that the development of the polycentric form of the cities will increase the intensity of use of personal cars at the expense of other transport modes, yet, it does not necessarily lead to a longer commute - which may be caused by the development of lateral suburb to suburb trips.

Marada (2006) and Urbánková, Ouředníček (2006) dealt with the dispersion of transport flows in Prague and its hinterland. The authors show the above-average fast increase in intensity of car transport in Prague, which is explained by the influence of a number of factors, among others also by lifestyle change connected to the development of residential and commercial suburbanization. As a result a rapid growth in traffic is taking place, in particular in the Prague outer cordon, where traffic intensity grew more than three times between 1990 and 2003. This intensive growth is connected, among others, also with cross-commuting. The authors state in this connection that while new inhabitants of suburbs work mainly in Prague, a number of jobs in its hinterland is taken by Prague inhabitants. Therefore residential and commercial suburbanisation increase traffic peformance in both directions (Urbánková, Ouředníček 2006). 


\subsection{Transport and polycentricity of the urban system}

The growing individual mobility does not have an effect only in cities but it also improves accessibility of the neighbouring centres. Transport thus becomes one of the significant conditions of urban system polycentricity. The study of mutual links between transport and urban system polycentricity is less frequently represented in transport geography literature.

Gren (2003) provides an analysis of Trans-European Transport Networks construction impacts. The author maintains that massive investment in transport structure in European peripheral areas contributes to the emergence of regional growth centres in three ways: due to better accessibility the centres increase their hinterland, by means of higher speed connections they support their contacts with the EU centre and moreover, they improve their accessibility among themselves. Regional growth centres could even gradually form a kind of counterbalance to the Blue Banana. ${ }^{1}$ Gren interprets this situation as a process of emergence of a polycentric situation in the EU, as examples of new polycentric growth regions he gives the following groups of cities: Lyon - Barcelona - Nice, Vienna Bratislava, Prague - Munich and Øresund (Copenhagen - Malmö).

Analyses of links between transport and polycentricity of the urban system very often also focus on discussing the impact of the construction of new transport infrastructure on spatial behaviour (territoriality) of the population in a certain area. The influence of the Øresund fixed link construction is dealt with by Matthiessen (2004) and recently also by Knowles, Matthiessen (2009). Thanks to this link mutual contacts (including commuting or migration) between Sjælland (Denmark) and Skåne (Sweden) are growing, yet the growth rate does not correspond with the original assumptions. ${ }^{2} \mathrm{~A}$ greater plurality of choices (polycentricity given by the possibility of choosing between Malmö and Copenhagen) connected with a slight change in territoriality in both areas is obvious, but the slower growth of contacts document the fact that the existence of a quality transport connection represents only one of many conditions necessary for the development of polycentricity. Additional conditions include, among others, cultural, linguistic and economic similarity. Some authors state in this connection that transport is an essential precondition but not a sufficient one (see e.g. Rodrigue et al. 2006). These findings can also be supported by the results of an analysis conducted by Heddebaut (2001). She arrived at the conclusion that the construction of the Channel Tunnel is not a sufficient prerequisite for the emergence of a bi-national city Dover - Calais.

In Czech geographic literature, Hampl et al. (1987) or Hampl (2005) proved the existence of intensive links within a settlement system in connection with good transport accesibility. The authors defined so called integrated systems of centres

\footnotetext{
1 Mulíček (2008) defines the Blue Banana as a highly urbanized area, stretching from South East England to Northern Italy. Cities like London, Brussels, Amsterdam, Cologne, Frankfurt, Zurich or Milan are part of it.

2 The slower growth of contacts between Sjælland and Skåne regions and between the cities of Copenhagen and Malmö is especially evident when the development of traffic intensity and interaction generated by the Øresund fixed link is compared with the impact of an analogous project across the Great Belt Strait. The difference between both fixed links, however, lies in the fact that Great Belt fixed link is a national construction, since on both sides it connects regions in Denmark (Knowles, Matthiessen 2009).
} 
through relativisation of work and school commuting to their straight distance while the prerequisite was their good transport connectivity. There is a clear link between the concepts of polycentricity and integrated systems of centers because the development of regional work distributon and mutual relational interconnectivity ranks among the fundamental properties of metropolitan areas (ie. one type of integrated systems of centres) according to Hampl (2005). These are important features of a polycentric settlement system too.

\subsection{Transport, mobility and polycentricity - positive and negative impacts}

The growing transport intensity, combined with polycentric spatial development, has ambivalent social impacts (nevertheless, in the interest of correctness, it is necessary to emphasize that both positive and negative assessment of impacts often tends to be subjective).

A negative impact of metropolitan regions polycentricity is the growing dependence on cars as individual mobility sources. People without access to a car are thus, as a result of these changes, discriminated against since accessibility of socio-economic opportunities is getting worse for them. The issues of transport generated social exclusion are dealt with in detail by Kenyon et al. (2002); poor accessibility of jobs for people without cars in the Barcelona metropolitan region is noted by Cebollada (2009).

The risk of worsening local socio-economic situation also entails the development of polycentricity in the urban system, since good accessibility of a higher number of stronger centres in particular could mean the danger of exhaustion of local sources. This type of danger is described in geographic literature as the pump effect. The risk of degradation of the city of Lille to the position of a mere satellite of Paris or Brussels in connections with the construction of high-speed railway is discussed by Bruyelle, Thomas (1994).

A good accessibility of a higher number of centres can, on the other hand, represent an impulse accelerating the development of the given place, as a result of the fact that the population has a plurality of choices concerning the place of their daily activities. Among the positive effects of this type it is possible to include e.g. accessibility of more jobs, namely better quality and better paid jobs, more alternatives for spending leisure, a possible change in consumption patterns, etc. Positive impacts of better accessibility of a higher number of centres are pointed out e.g. by Holl (2007). Garmendia et al. (2008) take the example of the city of Ciudad Real to show that plurality of choices, provided by easier accessibility of the Madrid metropolitan region after finishing of high-speed railway, increases the city's attractiveness and helps increase its territorial importance.

\section{Polycentric links among centres in the eastern part of the Czech Republic - aim and method}

\subsection{The aim of the paper}

The aim of the paper is both to establish potential transport-based polycentric relations between urban centres in the eastern part of the Czech Republic, and to 
provide brief benefit quantification, supplied by potential polycentricity to the respective centres.

In this paper, polycentricity potential is identified on the basis of existing transport interactions between the centres. However, for their specification, it is not possible to use passenger car transport data (although nowadays this mode of transport is predominant), as the total number of cars on individual road sections may be determined, but the direction of their movement is not known (i.e. the initial and terminal points of their journey). Transport interactions between the centres are thus determined by means of the number of public transport connections on offer. This fact does not mean a decline in the credibility of results, since public transport supply follows the existing commuting flows to work and services, i.e. the basic processes generating interactions between centres.

Polycentricity benefit quantification is carried out by means of the calculation of the daily economic potential, whose size makes it possible to quantify economic activity, accessible daily for the individual centres on top of their own supply, thanks to easy accessibility of the neighbouring centres. By means of the daily economic potential it is possible to express the amount of benefit provided to the population of the individual centres by higher level of transport accessibility.

\subsection{Notes on the method}

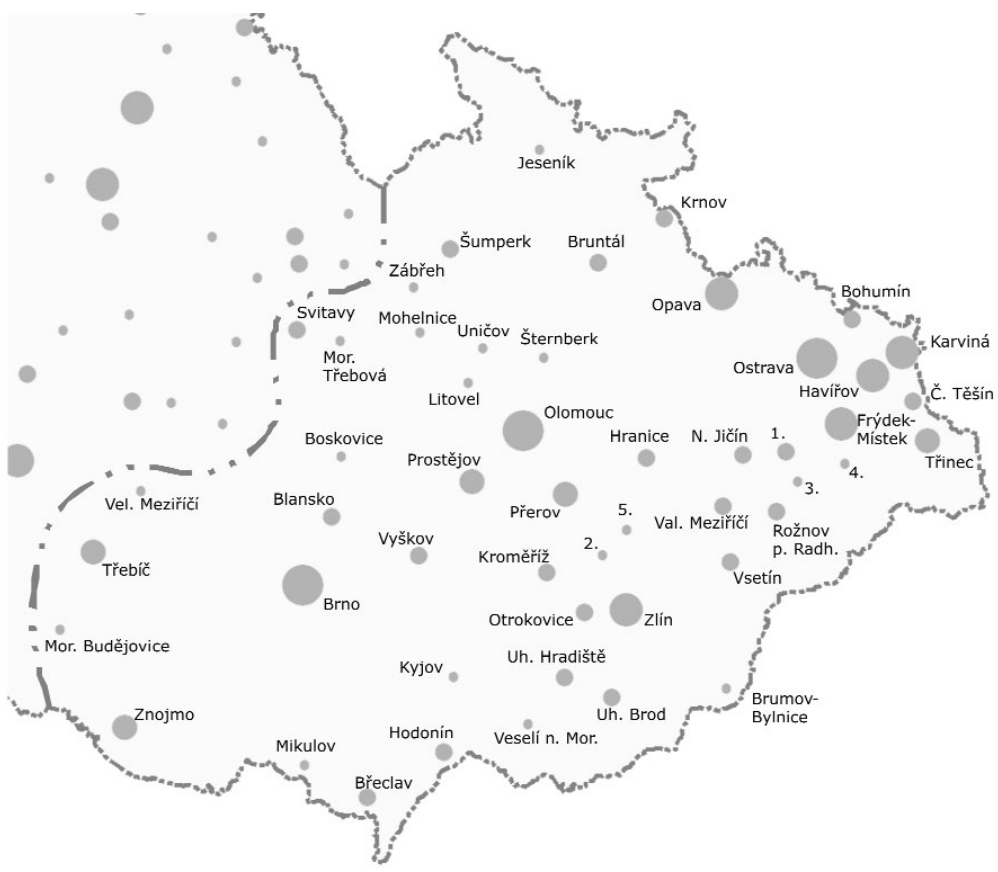

Fig. 1: Centres in the eastern part of the Czech Republic

Notes: 1. Kopřivnice, 2. Holešov, 3. Frenštát p. Radh., 4. Frýdlant n. Ostr., 5. Bystřice p. Host. Source: Sýkora, Mulíček (2009) 
Transport interactions are examined between 51 centres in the eastern part of the Czech Republic, for their overview see Fig. 1. The boundary lines of the studied area have been drawn to interfere with the existing transport interactions between centres as little as possible. The centres were determined by L. Sýkora and O. Mulíček, especially for the "Support to Polycentric Regional Development" (POLYREG, WD-40-07-1) project. This paper is one of the outcomes of the project. The criteria used to determine the centres are described, among others, in Sýkora, Mulíček (2009). Here, due to lack of space, it is only stated that the centres were determined using commuting data from the 2001 census, each centre having a minimum of 1,000 occupied jobs and being the destination of at least one biggest commuting flow from another municipality and the whole travel-to-work region had to have a population of at least 15 thousand.

In view of the fact that daily economic potential is used in the analyses, the paper only uses such transport interactions that make daily interactions of centres possible. A maximum time interval (hereinafter time-range of centre) was therefore set for the individual population categories of the centres, making the daily journey there and back possible. The purpose of the time-range is to exclude intensive transport interactions between big but remote centres (e.g. between Brno and Ostrava). The

Tab. 1: The calculation of the time-range of centres

\begin{tabular}{|c|c|c|c|c|}
\hline Population & $\begin{array}{c}\text { Average } \\
\text { commuting time } \\
\text { (min.) }\end{array}$ & Index & $\begin{array}{c}\text { Time-range } \\
\text { (accurate) } \\
\text { (min.) }\end{array}$ & $\begin{array}{c}\text { Time-range } \\
\text { (approximate) } \\
\text { (min.) }\end{array}$ \\
\hline$-14,999$ & 29.9 & 1.5 & 45 & 45 \\
\hline $15,000-29,999$ & 32.8 & 1.5 & 49 & 50 \\
\hline $30,000-49,999$ & 34.8 & 1.6 & 56 & 55 \\
\hline $50,000-99,999$ & 37.1 & 1.7 & 63 & 65 \\
\hline $100,000-$ Brno & 44.2 & 1.8 & 80 & 105 \\
\hline Prague & 53.7 & 2.0 & 107 & 80 \\
\hline
\end{tabular}

Notes:

- average commuting time was calculated as a weighted mean of daily commuting time for all centres of respective population size category, the number of daily commuters was used as a weight;

- time-range (accurate) - multiple of average commuting time and corresponding index;

- indices ranging from 1.5 to 2.0 (column 3) were included into the time-range calculation because of relatively small difference in average commuting time between population categories of centres; values above 1 reflect people's willingness to commute to school and work from distances longer than average; this willingness increases with the hierarchical order of the centre analysed; the index diferentiation from 1.5 to 2.0 enables quantification of the differences of willingness to commute to centres of different hierarchical importance; the resulting time-ranges of size categories are treated generously on purpose so as not to exclude any potential intercity relations

Source: ČSÚ (2004) 
time-range of centres was derived from the mean commuting time to work with daily frequency in 2001; Tab. 1. shows the way in which it was set (the analysis is based on the data from the last column).

For each pair of centres the number of bus and train connections for the whole day, corresponding to the time-range of the bigger of the two centres, was then looked up in the referential timetable (valid for 2007/2008). Public transport connections were only looked up for one direction (reciprocity of supply was anticipated) and further set conditions had to be met for the connection inclusion, concerning changes, minimum length of the operation period of the connection, etc.

The daily economic potential (for more details on this accessibility rate see e.g. Holl 2007 or Gutiérrez 2001) is a gravity based measure, based on the idea that the number of opportunities accessible to an inhabitant of a particular place is influenced both by the number of opportunities in the neighbouring centres (direct correlation), and by their distance or spatial remoteness (inverse correlation). In this paper, the calculation of the daily economic potential is based on the number of disposable occupied jobs. The calculation includes both jobs in the centre itself and also the jobs from all neighbouring centres with which the centre in question maintains transport interactions. The result is a sum of jobs potentially easily accessible to the population of the given municipality. The daily economic potential of the centre $i\left(P_{i}\right)$, for the purposes of this analysis, is calculated according to the following formula:

$$
P_{i}=M_{i}+\sum \frac{M_{j}}{T_{i j}{ }^{\alpha}},
$$

where $M_{i}$ is the number of occupied jobs 3 in centre $i, M_{j}$ is the number of occupied jobs in all centres that have a transport link to the centre $i, T_{i j}$ is the spatial remoteness of centres $i$ and $j$, expressed by the intensity of their transport link (namely the supply of bus and train connections; the way of recalculating the frequency of public transport to the measure of remoteness of the centres $i$ and $j$ is shown in Tab. 2). Exponent $\alpha$ expresses the degree of dependence of the changes in interaction on the growing spatial remoteness; for the sake of simplicity, the present analysis uses $\alpha=1$ (for a brief discussion on setting the exponent $\alpha$ see e.g. Holl 2007).

3 Occupied jobs - is the sum of employed people with permanent residence in the given municipality and the balance of inward and outward commuting in the given municipality (ČSÚ 2004). 
Tab. 2: Public transport frequency as a measure of the spatial remoteness of centre-pairs and the method of daily economic potential calculation $\left(\mathrm{P}_{\mathrm{i}}\right)$

\begin{tabular}{|c|c|c|}
\hline $\begin{array}{c}\text { Public transport }- \\
\text { number of connections }\end{array}$ & Index & Calculation of $\mathbf{P}_{\mathbf{i}}$ \\
\hline 50 and more & 0.5 & $\mathrm{M}_{\mathrm{j}} \times 0.5$ \\
\hline $40-49$ & 0.4 & $\mathrm{M}_{\mathrm{j}} \times 0.4$ \\
\hline $30-39$ & 0.3 & $\mathrm{M}_{\mathrm{j}} \times 0.3$ \\
\hline $20-29$ & 0.2 & $\mathrm{M}_{\mathrm{j}} \times 0.2$ \\
\hline $10-19$ & 0.1 & $\mathrm{M}_{\mathrm{j}} \times 0.1$ \\
\hline $5-9$ & 0.05 & $\mathrm{M}_{\mathrm{j}} \times 0.05$ \\
\hline
\end{tabular}

Notes:

- indices ranging from 0.05 to 0.5 facilitate the conversion from public transport frequency to the level of spatial remoteness of centre-pairs; the index values are intentionally lower than 1 because the neighbouring centres contribute only partially to the number of jobs available in the centre $i$, the reason being the necessity to commute. The increasing public transport frequency means the growing contribution of adjacent centre to the value of daily economic potential; indices ranging from 0.05 to 0.5 are a result of an informed guess of the perception of spatial barrier in relation to the offered frequency of public transport;

- $\mathrm{P}_{\mathrm{i}}$ - daily economic potential, $\mathrm{M}_{\mathrm{j}}$ - number of jobs

\section{Polycentric links among centres in the eastern part of the Czech Republic - results}

Fig. 2 shows transport interactions between centres in the eastern part of the Czech Republic. The most intensive transport interactions mutually integrate urban systems in Ostrava region and in Central Moravia (the belt throughout the Morava river area from Šmperk down to Břeclav). The city of Brno is interconnected with some of its neighbours by a frequented public transport supply. On the other hand, some of the more peripheral centres have a weak connectivity to the system of identified transport interactions - these are mainly southwestern and northern parts of the area in question (Znojmo area, the Jeseníky Mountains). The town of Jeseník is the only centre in the eastern part of the Czech Republic that, under the given conditions (i.e. focus on daily interactions), does not maintain transport contacts with any of its neighbours.

The spatial pattern of transport interactions between centres in Fig. 2 shows a relatively clear resemblance with the system of long-distance railway routes and major roads.

In the eastern part of the Czech Republic, there are the following types of spatial organization of transport interactions:

- Radial pattern of transport interactions: this spatial group is characterized by interconnecting a high number of middle-sized and weaker centres with one centre 
with higher hierarchical importance. A typical example is the situation in the surroundings of Brno where there is a complete system of radial routes.

- Polycentric pattern of transport interactions: a typical feature is the existence of a high number of mutually overlapping transport interactions which, in a given area, provide connections of a high number of centres among themselves. A pattern of this type is evident mainly in Ostrava region and in Central Moravia. On a lower public transport frequency level even integration of both areas may occur.

- The arrangement of transport interactions in the remaining (mostly peripheral) areas does not show any clear spatial pattern.

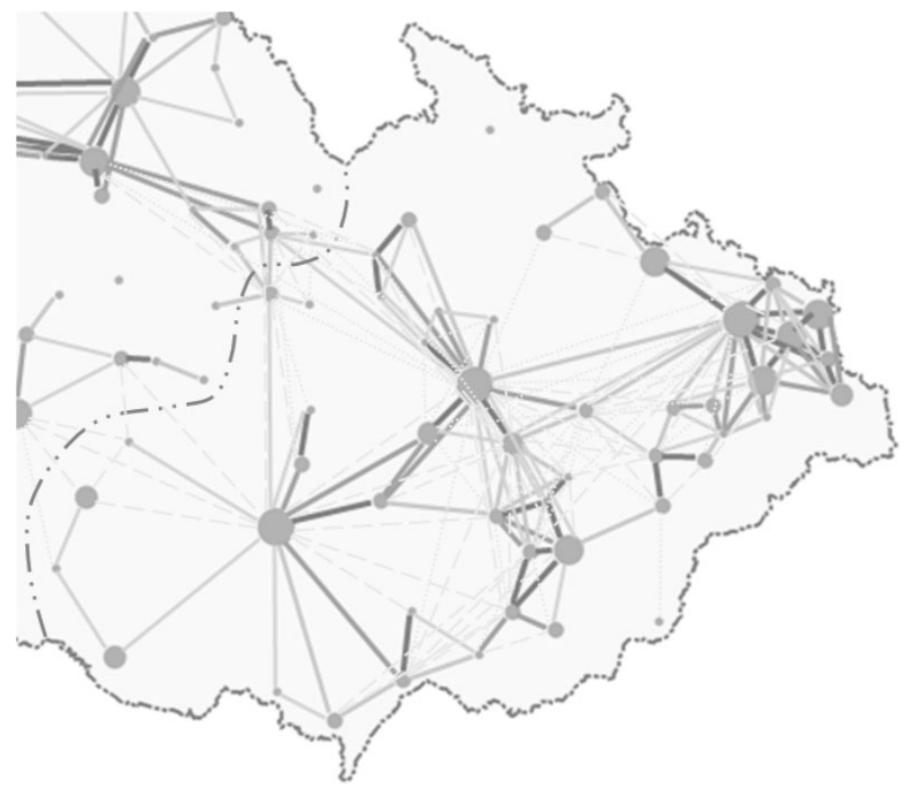

Public transport number of connections:

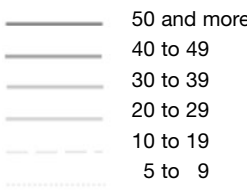

Fig. 2: Centres in the eastern part of the Czech Republic - transport relations Source: train and bus timetables 2007/2008

Following the focus of this paper, polycentric arrangement of transport interactions is particularly interesting. Unlike the radial arrangement of public transport supply, this pattern provides the inhabitants of the concerned cities with potential plurality of choices of places for the realization of daily activities (economic activity, shopping, cultural events, entertainment, leisure activities, etc.). Leaving aside cities high in the Czech urban hierarchy, such as Brno, Ostrava, Olomouc or Zlín (according to Hampl 2005 these are mezo-regional centres in the eastern part of the Czech Republic), it is possible to state that from the point of view of transport, people having the highest plurality of choices for realization of their daily activities are the inhabitants of the following cities: Přerov, Hranice, Otrokovice, Frýdek-Místek, Kroměřǐž, Svitavy, Uherské Hradiště, Valašské Meziř́ičí, Bohumín, Hodonín, Prostějov, Holešov, and Zábřeh. On the opposite side of the spectrum there are the cities of Jeseník, Brumov- 
Bylnice, Znojmo, Mikulov, Boskovice, Bruntál, Krnov, Kyjov, Moravská Třebová, and Moravské Budějovice. In these cities the plurality of choices for realization of daily activities is severely limited. The above mentioned cities were chosen on the basis of order of a node, which is an indicator of connectivity that, in graph theory, denotes the number of edges coming out of the individual nodes of a graph (for a definition of indicators used in graph theory see e.g. Kansky 1963). Fig. 3 shows a complete ranking of all centres in the eastern part of the Czech Republic according to order of a node.

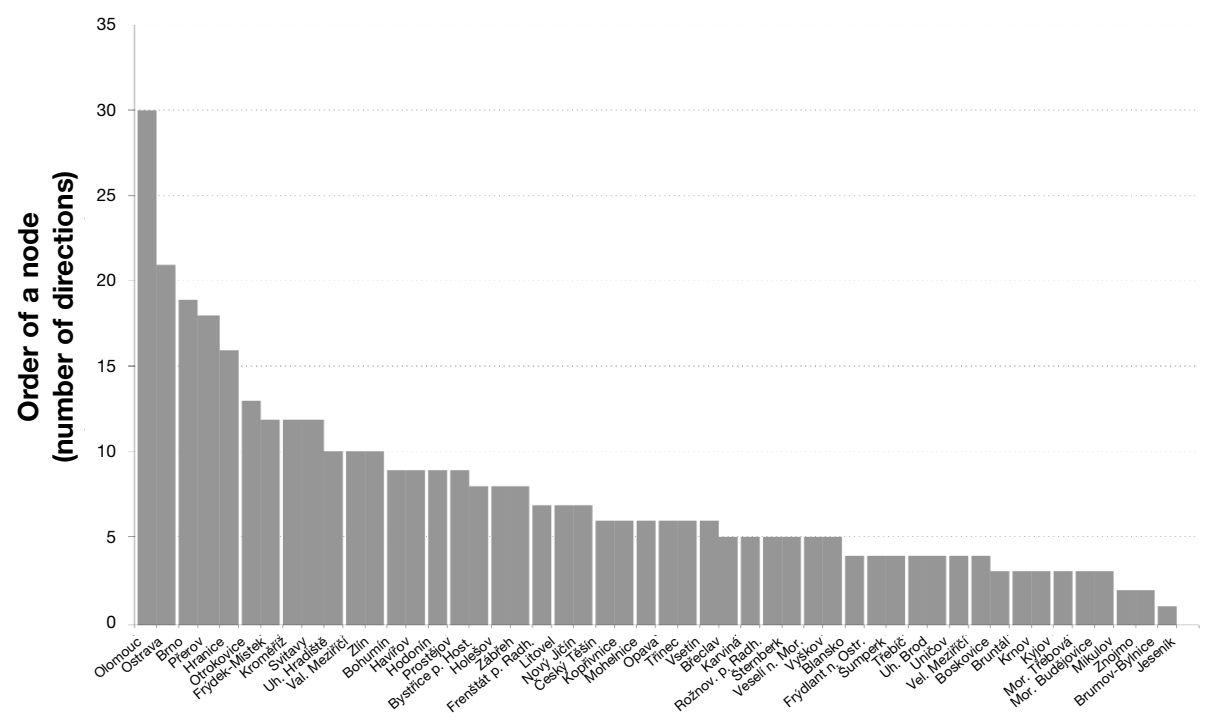

Fig. 3: Centres in the eastern part of the Czech Republic - order of a node Source: train and bus timetables 2007/2008

To be able to quantify the benefit brought to the population of the cities by the polycentric pattern of transport interactions, the daily economic potential was calculated for the needs of this paper.

The biggest number of jobs, according to Fig. 4, is accessible for the population of big cities and also for the population of cities located in areas with a polycentric pattern of transport interactions, i.e. in areas with good accessibility of a number of neighbouring centres. Provided that the close and accessible centres are also relatively significant, as far as jobs are concerned, the final number of disposable jobs compared with the actual number of occupied jobs (i.e. jobs located directly in the analyzed centre) can increase even several fold. In absolute terms, the highest number of jobs is available for the population of the biggest cities (namely Brno, Ostrava, Olomouc) and further for the inhabitants of centres in Ostrava region and in Central Moravia. In Ostrava region, apart from Ostrava, seven more cities fall into two highest categories (more than 150 or 100 thousand jobs respectively), in Central Moravia, apart from 
Olomouc, five more centres can be identified. At the same time, all of these cities have high values of order of a node, which is a proof of the fact that they belong to polycentric transport structures. It is interesting that Zlin falls only into the third category (50 to 99 thousand accessible jobs). The reason for this ranking is the fact that Zlín is connected by strong transport interactions to mostly weaker neighbouring centres. An overview of ten cities with the highest numbers of accessible jobs can also be found in Tab. 3 .

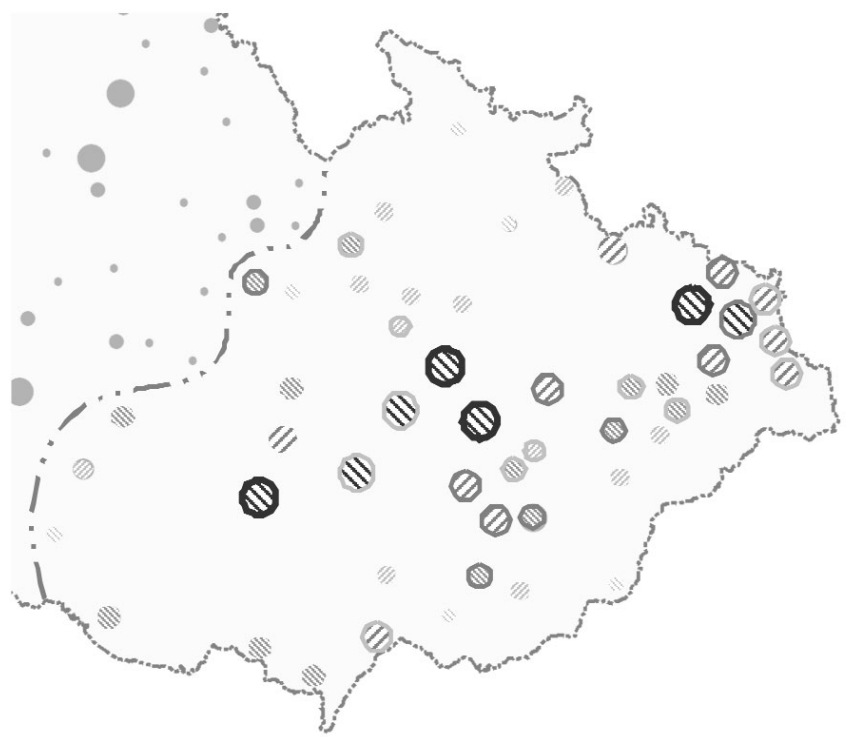

Centres - daily economic potential (thousands of accessible jobs):

W/I 150,0 and more

Ni. 100,0 to 149,9

50,0 to 99,9

25,0 to 49,9

0,0 to 24,9

Centres - weighted order of a node:

25,0 and more

15,0 to 24,9

10,0 to 14,9

Fig. 4: Centres in the eastern part of the Czech Republic - daily economic potential Source: ČSÚ (2004)

When focusing on value increase of accessible jobs due to intensive transport interactions (see Fig. 5; an overview of ten cities with the biggest absolute and relative increase is also shown in Tab. 3), it is possible to point out the following established facts:

- big increase in absolute terms often occurs in cities well connected to other big centres, such as Bohumín, Karviná, Český Těšín, Frýdek-Místek, but also Opava, Frýdlant n. Ostr., Frenštát p. Radh., Kopřivnice and Nový Jičín in Ostrava region and likewise Prostějov, Přerov, Hranice, Hulín, Vyškov, Kroměříž, Otrokovice and Uherské Hradiště in Central Moravia; similarly, Blansko, Hodonín and Břeclav profit from the strong link to Brno;

- big increase in relative terms is shown by conveniently situated smaller centres, mainly Bohumín, Český Těšín, Frýdlant n. Ostr., and Frenštát p. Radh. in Ostrava region, Litovel, Hranice, and Hulín in Central Moravia and Mikulov, not far from Brno;

- big cities have a specific position - Ostrava and Olomouc show a big absolute increase in the number of jobs, but a low relative increase (the result of polycentric 
links to a number of neighbouring weaker centres); near Brno and Zlín there are even lower absolute increases (especially in the case of Brno, this is the result of a combination of a radial pattern of transport links connected with the occurrence of substantially weaker centres in its hinterland).

Based on the gained results, it can be assumed that the polycentric pattern of transport interactions probably offers a certain advantage to the centres, as the highest absolute numbers of jobs and their biggest absolute and relative increases usually occur in Ostrava region and in Central Moravia, i.e. the very regions typically showing a high transport potential to polycentricity. Polycentric urban systems thus offer, mainly in comparison with transport isolated centres, but partly also in comparison with centres which are part of radial transport interactions, more attractive living conditions, since they enable plurality of choices of a place for the realization of daily activities. This can be well illustrated by an example from the labour market: in case of problems in one part of a polycentric urban system, the situation can be solved by job supply in another part. Therefore it is even possible to speculate about higher development dynamism of polycentric spatial structures, and in a long-term horizon, even about the growing socio-economic divergence between transport-linked and transport-isolated centres.
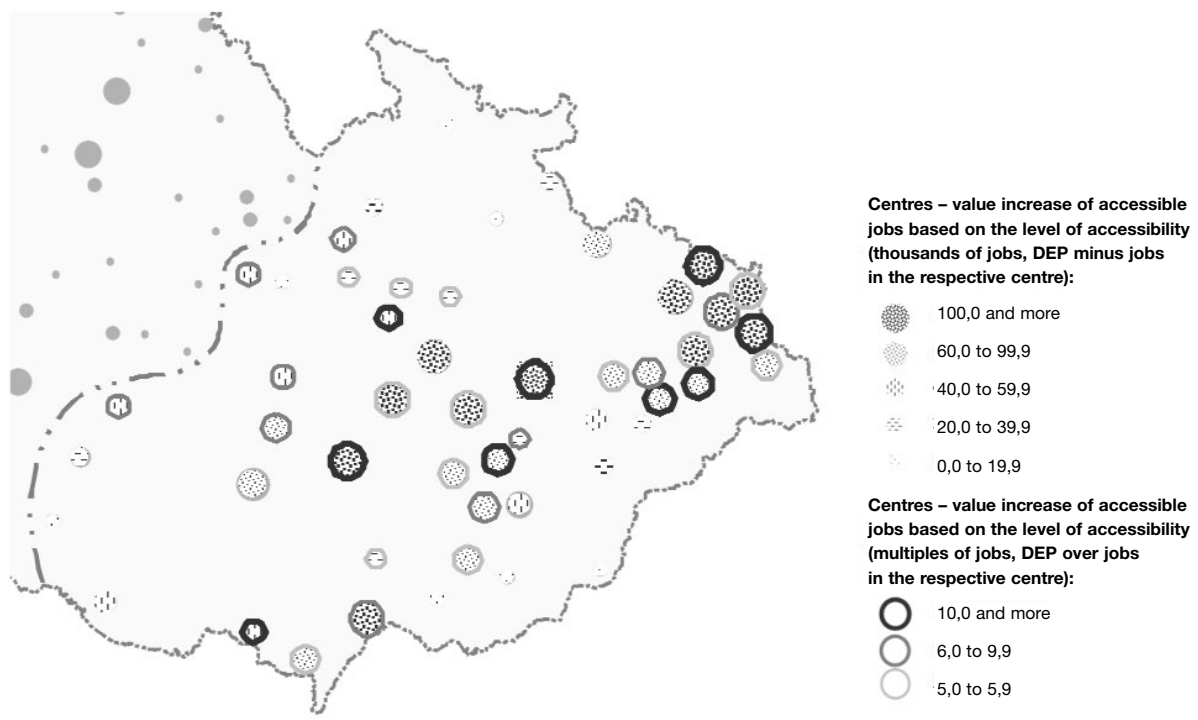

Fig. 5: Centres in the eastern part of the Czech Republic - daily economic potential (DEP), absolute and relative value increase of accessible jobs based on the level of accessibility

Source: ČSÚ (2004) 
Tab. 3: Daily economic potential (DEP) - 10 centres with the biggest DEP, 10 centres with the biggest absolute and 10 centres with the biggest relative value increase of accessible jobs based on the level of accessibility

\begin{tabular}{|c|c|c|c|c|c|c|c|c|}
\hline & Centre & $\begin{array}{c}\text { DEP } \\
\text { (jobs, abs.) }\end{array}$ & & Centre & $\begin{array}{l}\text { DEP minus } \\
\text { jobs in the } \\
\text { respective } \\
\text { centre } \\
\text { (jobs, abs.) }\end{array}$ & & Centre & $\begin{array}{c}\text { DEP over } \\
\text { jobs in the } \\
\text { respective } \\
\text { centre } \\
\text { (multiples) }\end{array}$ \\
\hline 1. & Brno & 298,791 & 1. & Vyškov & 161,847 & 1. & Frýdlant n. O. & 18.4 \\
\hline 2. & Ostrava & 288,966 & 2. & Olomouc & 156,970 & 2. & Český Těšín & 15.0 \\
\hline 3. & Olomouc & 223,564 & 3. & Prostějov & 147,107 & 3. & Frenštát p. R. & 14.4 \\
\hline 4. & Vyškov & 175,967 & 4. & Haviŕrov & 133,240 & 4. & Mikulov & 12.9 \\
\hline 5. & Prostějov & 175,886 & 5. & Přerov & 130,020 & 5. & Vyškov & 12.5 \\
\hline 6. & Přerov & 157,632 & 6. & Český Těšín & 127,181 & 6. & Holešov & 11.8 \\
\hline 7. & Havírov & 154,455 & 7. & Bohumín & 124,387 & 7. & Bohumín & 11.7 \\
\hline 8. & Frýdek-Místek & 147,999 & 8. & Frýdek-Místek & 122,491 & 8. & Hranice & 10.6 \\
\hline 9. & Karviná & 139,475 & 9. & Ostrava & 121,787 & 9. & Litovel & 10.1 \\
\hline 10. & Český Těšín & 136,283 & 10. & Hodonín & 118,013 & 10. & Blansko & 8.6 \\
\hline
\end{tabular}

Source: ČSÚ (2004)

\section{Conclusion}

Areas with a differing spatial pattern of daily transport contacts were identified among 51 centres in the eastern part of the Czech Republic. Ostrava region and Central Moravia (the belt throughout the Morava river area from Šumperk down to Břeclav) show a polycentric pattern of transport interactions, broader hinterland of Brno is characterized by radial structure of these interactions. It has been demonstrated by the calculated daily economic potential that urban systems interconnected in a polycentric way provide the population with an advantage, consisting in easy accessibility of a higher number of jobs - leaving aside the city of Brno, it can be stated that centres in Ostrava region and in Central Moravia show both the highest values of this indicator and the highest absolute and relative value increase of accessible jobs provided by the existing intensive transport interactions. The population of centres situated in these areas can thus profit from greater plurality of choices of places for the realization of their daily activities.

In connection with the gained results it is also possible to define relevant topics for future research. Its aim may be the verification of the hypothesis, whether transportlinked centres have higher socio-economic dynamism compared to transport-isolated centres, or alternatively, future research could focus on the justification of the claim that transport well equipped potential polycentric areas really show signs of 
polycentric spatial interactions, using e.g. an analysis of the existing commuting or migration flows, as this paper only deals with the assessment of the potential for polycentric development, based on transport interactions. In view of the fact that transport is only one of the factors of the development, it is possible that without further integration mechanisms real polycentricity in the eastern part of the Czech Republic need not become evident at all. Investigators of the "Support to Polycentric Regional Development" (POLYREG, WD-40-07-1) project are going to deal with both types of analyses that are beyond the scope of this paper.

\section{Acknowledgement}

The article is based on research funded by the grant WD-40-07-1 "Support to Polycentric Regional Development" (POLYREG) of the Ministry for Regional Development of the Czech Republic.

\section{References}

BRUYELlE, P., THOMAS, P. R. (1994): The impact of the Channel Tunnel on Nord-Pas-de-Calais. Applied Geography 14, 87-104.

CEBOLLADA, À. (2009): Mobility and labour market exclusion in the Barcelona Metropolitan Region. Journal of Transport Geography 17, 226-233.

GARMENDIA, M., UREÑA, J. M., RIBALAYGUA, C., LEAL, J. and CORONADO, J. M. (2008): Urban residential development in isolated small cities that are partially integrated in metropolitan areas by high speed train. European Urban and Regional Studies 15 (3), 249-264.

GREN, J. (2003): Reaching the Peripheral Regional Growth Centres: Centre-periphery convergence through the Structural Funds' transport infrastructure actions and the evolution of the centre-periphery paradigm. European Journal of Spatial Development 2003 (3), 1-22.

GUTIÉRREZ, J. (2001): Location, economic potential and daily accessibility: an analysis of the accessibility impact of the high-speed line Madrid - Barcelona - French border. Journal of Transport Geography 9 , 229-242.

GUTIÉRREZ, J. and GARCÍA-PALOMARES, J. C. (2007): New spatial patterns of mobility within the metropolitan area of Madrid: Towards more complex and dispersed flow networks. Journal of Transport Geography $15,18-30$.

HAMPL, M., GARDAVSKÝ, V. and KÜHNL, K. (1987): Regionální struktura a vývoj systému osídlení ČSR. Praha, Univerzita Karlova.

HAMPL, M. (2005): Geografická organizace společnosti v České republice: transformační procesy a jejich obecný kontext. Praha, Univerzita Karlova.

HEDDEBAUT, O. (2001): The binational cities of Dover and Calais and their region. GeoJournal 54, 61-71.

HOLL, A. (2007): Twenty years of accessibility improvements. The case of the Spanish motorway building programme. Journal of Transport Geography 15, 286-297.

KANSKY, K. J. (1963): Structure of Transportation Networks: Relationships between Network Geometry and Regional Characteristics. Chicago, The University of Chicago.

KELLERMAN, A. (2006): Personal mobilities. Oxon, Routledge.

KENYON, S., LYONS, G. and RAFFERTY, J. (2002): Transport and social exclusion: investigating the possibility of promoting inclusion through virtual mobility. Journal of Transport Geography 10, $207-219$.

KNOWLES, R. D. and MATTHIESSEN, Ch. W. (2009): Barrier effects of international borders on fixed link traffic generation: the case of _resundsbron. Journal of Transport Geography 17, 155-165.

MARADA, M. (2006): Dopravní vztahy v Pražském městském regionu. In: OUŘEDNÍČEK, M. (ed.): Sociální geografie Pražského městského regionu (64-78). Praha, Univerzita Karlova v Praze. 
MATTHIESSEN, W. Ch. (2004): The Öresund Area: Pre- and post-bridge cross-border functional integration: the bi-national regional question. GeoJournal 61, 31-39.

McBRIDE, P. J. (1996): Human Geography. Systems, Patterns and Change. Surey, Nelson.

MULÍČEK, O. (2008): Geografie sídel. In: TOUŠEK, V., KUNC, J., VYSTOUPIL, J. (eds.): Ekonomická a sociální geografie (97-130). Plzeň, Vydavatelství a nakladatelství Aleš Čeněk.

PEDERSEN, P. O. (2001): Freight transport under globalisation and its impact on Africa. Journal of Transport Geography 9, 85-99.

RODRIGUE, J. P., COMTOIS, C., SLACK, B. (2006): The Geography of Transport Systems. New York, Routledge.

SEIDENGLANZ, D. (2008): Geografie dopravy. In: TOUŠEK, V., KUNC, J., VYSTOUPIL, J. (eds.): Ekonomická a sociální geografie (231-269). Plzeň, Vydavatelství a nakladatelství Aleš Čeněk.

SCHWANEN, T., DIELEMAN, F. M. and DIJST, M. (2001): Travel behaviour in Dutch monocentric and policentric urban systems. Journal of Transport Geography 9, 173-186.

SÝKORA, L. (2002): Suburbanizace a její sociální, ekonomické a ekologické důsledky. Praha, Ústav pro ekopolitiku.

SÝKORA, L. and MULÍČEK, O. (2009): The micro-regional nature of functional urban areas (FUAs): lessons from the analysis of Czech urban and regional system. Urban Research and Practice 2009 (3), in print.

URBÁNKOVÁ, J., OUŘEDNíČEK, M. (2006): Vliv suburbanizace na dopravu v Pražském městském regionu. In: OUŘEDNÍČEK, M. (ed.): Sociální geografie Pražského městského regionu (79-95). Praha, Univerzita Karlova v Praze.

WHEELER, J. O. and MULLER, P. O. (1981): Economic Geography. New York, Chichester, Brisbane, Toronto, Singapore, Wiley.

ČSÚ (2004): Sčítání lidu, domů a bytů k 1. 3. 2001 - dojíždka a vyjíždka k 1. 3. 2001. Praha, ČSÚ.

Train and bus timetables 2007/2008

Résumé

Dopravní vztahy mezi stř̌edisky osídlení ve východní části ČR a jejich potenciál k formování polycentricity

Doprava patří $\mathrm{k}$ důležitým faktorům, které ovlivňují uspořádání prostorových vztahů a vytvářenî prostorových interakcí ve společnosti. Tuto tezi lze aplikovat i na problematiku formování vazeb v rámci sídelního systému. V souvislosti s tím je možné zdůraznit, že organizace dopravních vazeb mezi středisky osídlení do značné míry předurčuje i jejich monocentrické, respektive polycentrické uspořádání. $\mathrm{V}$ př́ispěvku je pozornost věnována rozboru těchto souvislostí jak v teoretické, tak i v praktické rovině. Na př́kladu území ve východní části Česka jsou prostřednictvím nabídky spojů hromadné dopravy identifikovány dopravní vztahy mezi 51 středisky, které umožňují vznik každodenních interakcí mezi nimi. Kromě typologie prostorové konfigurace nalezených dopravních vazeb je výstupem článku i kvantifikace přínosů, které potenciální polycentričnost obyvatelům středisek přináší (např. vyšší pluralita voleb místa realizace každodenních činností). Př́nosy jsou analyzovány prostřednictvím výpočtu tzv. denního ekonomického potenciálu vyjádřeného jako celkové množství dostupných pracovních příležitostí.

Daniel Seidenglanz Masaryk University, Faculty of Science, Department of Geography Brno, Czech Republic Kotlärská 2, 611 37, Brno tel.: +420 549497228 e-mail.: seidenglanz@geogr.muni.cz 